\title{
Direct comparison of boron, phosphorus, and aluminum gettering of iron in crystalline silicon
}

\author{
S. P. Phang a) and D. Macdonald \\ School of Engineering, The Australian National University, Canberra ACT 0200, Australia
}

(Received 12 May 2010; accepted 28 February 2011; published online 13 April 2011)

\begin{abstract}
This paper presents a direct quantitative comparison of the effectiveness of boron diffusion, phosphorus diffusion, and aluminum alloying in removing interstitial iron in crystalline silicon in the context of silicon solar cells. Phosphorus diffusion gettering was effective in removing more than $90 \%$ of the interstitial iron across a range of diffusion temperatures, sheet resistances, and iron doses. Even relatively light phosphorus diffusions $(145 \Omega / \square)$ were found to give very effective gettering, especially when combined with extended low temperature annealing. Aluminum alloying was extremely effective and removed more than $99 \%$ of the implanted iron for a range of alloying temperatures and aluminum film thicknesses. In contrast, our experimental results showed that boron diffusion gettering is very sensitive to the deposition conditions and can change from less than $5 \%$ of the Fe being gettered to more than $99.9 \%$ gettered by changing only the gas flow ratios and the post-oxidation step. (C) 2011 American Institute of Physics. [doi:10.1063/1.3569890]
\end{abstract}

\section{INTRODUCTION}

Phosphorus doped n-type silicon solar cells have received considerable attention in recent years ${ }^{1-3}$ due partly to their greater resistance to metal contamination ${ }^{4-6}$ and also due to the absence of light-induced boron-oxygen defects. This makes n-type multicrystalline silicon an attractive substrate for producing efficient solar cells because its resistance to metal contamination could offset the detrimental effects of the inherently higher metal content of multicrystalline silicon. Nevertheless results from Coletti et al. ${ }^{6}$ have shown that $\mathrm{Fe}$ contamination can still degrade the lifetime in n-type multicrystalline silicon although to a lesser extent than in ptype material. Cuevas et al. ${ }^{1}$ and Coletti et al. ${ }^{6}$ have also shown that the lifetime of the n-type multicrystalline wafers can still be improved significantly after gettering. Of the gettering methods used for silicon solar cells, phosphorus diffusion, aluminum alloying, and boron diffusion have all been included to varying extents in the process steps of n-type multicrystalline solar cells. ${ }^{6,7}$ However, other than indirect comparisons in review papers, ${ }^{8,9}$ we are unaware of any direct comparisons of the gettering effectiveness of the different methods adapted to n-type silicon solar cells. This study provides a direct comparison of the gettering effectiveness of $\mathrm{B}, \mathrm{P}$, and $\mathrm{Al}$ in silicon using a relevant range of diffusion conditions and iron doses as well as a consistent iron detection method for each of the gettering agents.

It is well established that phosphorus diffusion is effective at gettering dissolved interstitial $\mathrm{Fe}$, one of the main metal impurities that can limit the lifetime of the material. ${ }^{8,10,11}$ Phosphorus diffusion gettering has an additional benefit in that phosphorus diffusion is required to form the emitter in ptype silicon solar cells, therefore it does not introduce extra steps to the production. In the case of n-type cells, phosphorus

\footnotetext{
a) Author to whom correspondence should be addressed. Electronic mail: pheng.phang@anu.edu.au.
}

diffusions can be used to form a back surface field. ${ }^{6,12,13}$ Aluminum alloying has also been shown to provide effective gettering of iron. ${ }^{14,15}$ However, the extent to which $\mathrm{Al}$ alloying can getter impurities from the whole thickness of the wafer is uncertain due to the very short alloying times used for contact firing (several seconds), and the fact that the Al layer is at the rear of the device. Therefore the thermal budget is likely insufficient for aluminum alloying to getter the metal impurities close to the front surface.

On the other hand, it is expected that boron diffusions, which would be required for front surface emitter formation in n-type multicrystalline silicon solar cells, will be less effective due to the low segregation coefficient for $\mathrm{Fe}$ at high temperature. ${ }^{16,17}$ However, there have also been reports that boron diffusion is effective in gettering metals under certain conditions, ${ }^{7,18,19}$ such as when the boron dose is supersaturated. Myers et al. ${ }^{18}$ demonstrated using ion implantation that metal impurities can segregate into the $\mathrm{Si}-\mathrm{B}$ precipitates when the boron dose is supersaturated for temperatures ranging from 800 to $1100^{\circ} \mathrm{C}$. Recently, Vähänissi et al. ${ }^{19}$ demonstrated impressive boron gettering effectiveness by adding extended low temperature annealing after $930^{\circ} \mathrm{C}$ boron diffusion. Their resultant iron concentration was more than an order of magnitude lower than the solid solubility of iron and also significantly lower than the expected value based on segregation to the boron-doped emitter. They concluded that the gettering effect observed was due to $\mathrm{Si}-\mathrm{B}$ precipitates formed in the supersaturated region close to the surface. Using n-type multicrystalline silicon, Libal et al. ${ }^{7}$ observed an increase in lifetime of more than $30 \%$ after boron diffusion without extended low temperature annealing. Their results are not expected on the basis of the segregation coefficient at high temperature and were explained as gettering by the boron rich layer (BRL), which can be considered as a $\mathrm{Si}$-B layer formed on the surface of the wafer when the $\mathrm{Si}$ surface is supersaturated with boron. ${ }^{20}$ In this paper, we will demonstrate that effective boron diffusion gettering of iron 
can be achieved using boron diffusion without the addition of extended low temperature annealing but is very sensitive to the gas flow ratios and the postoxidation step.

\section{EXPERIMENT METHODS}

Float-zone (FZ) single-crystal silicon wafers of (100) orientation, $230 \mu \mathrm{m}$ thickness, and resistivity of $0.6-1.0$ $\Omega \mathrm{cm}$ p-type boron doped were used in this study. Although p-type wafers are used to take advantage of the Fe-B pair breaking technique for measuring the interstitial Fe concentration, it is expected that the results are applicable to n-type silicon as well because the wafers are electronically intrinsic at the gettering temperatures considered. The $40 \times 40 \mathrm{~mm}$ wafers were chemically etched with a solution consisting of $\mathrm{HNO}_{3}: \mathrm{HF}: \mathrm{CH}_{3} \mathrm{COOH}(10: 1: 2)$ and RCA cleaned, and then implanted with ${ }^{56} \mathrm{Fe}$ at $70 \mathrm{keV}$ with a dose corresponding to a target volume concentration of $2.0 \times 10^{13}$ or $2.0 \times 10^{12}$ $\mathrm{cm}^{-3}$ in the center area of $30 \times 30 \mathrm{~mm}$. After cleaning, the implanted wafers, along with nonimplanted controls, were annealed at $900^{\circ} \mathrm{C}$ for $60 \mathrm{~min}$ in $\mathrm{N}_{2}$ to distribute the $\mathrm{Fe}$ uniformly throughout the wafer. The solubility of $\mathrm{Fe}$ in silicon at $900{ }^{\circ} \mathrm{C}$ is $4 \times 10^{13} \mathrm{~cm}^{-3}{ }^{21}$ so no significant precipitation or out-diffusion of Fe should occur. Both sides of the wafers were then etched by about $3 \mu \mathrm{m}$ to remove any residual implant damage at the surface, which has in any case been shown to be minimal at such low doses and energies. ${ }^{22}$ After surface passivation with $\mathrm{SiN}$ using plasma-enhanced chemical vapor deposition (PECVD) at $450{ }^{\circ} \mathrm{C}$, the interstitial $\mathrm{Fe}$ concentrations $\left(\left[\mathrm{Fe}_{\mathrm{i}}\right]\right)$ were then determined from quasisteady-state photoconductance (QSSPC) lifetime measurements ${ }^{23}$ applying the Fe-B pair breaking technique ${ }^{24,25}$ using capture cross-section values from Macdonald et al. ${ }^{26} \mathrm{Fe}-\mathrm{B}$ pair breaking was achieved using steady state light soaking under 1 sun intensity for $1 \mathrm{~min}$. A higher intensity xenon flash lamp was used to further break the pairs if the sample lifetime was less than $10 \mu \mathrm{s}$.

After stripping off the SiN layer using 10\% HF solution, and etching off another $3 \mu \mathrm{m}$ from each side of the wafers, sets of three wafers, containing the high dose $\left(2.0 \times 10^{13}\right.$ $\left.\mathrm{cm}^{-3}\right)$, low dose $\left(2.0 \times 10^{12} \mathrm{~cm}^{-3}\right)$, and nonimplanted control wafers were then subjected to either boron diffusion gettering, phosphorus diffusion gettering, or aluminum alloying gettering. Boron and phosphorus diffusion gettering were performed in quartz tube furnaces with dopant deposition by $\mathrm{BBr}_{3}$ and $\mathrm{POCl}_{3}$, respectively, followed by a drive-in in $\mathrm{N}_{2}$ ambient. For the last two boron diffusion sets labeled "B2," the $\mathrm{N}_{2}$ flow for the $\mathrm{BBr}_{3}$ was doubled during deposition, while keeping the other process parameters the same, to promote the growth of the BRL. Unless stated otherwise, all boron diffusions were terminated with a $6 \mathrm{~min}$ in situ post oxidation $^{7}$ at the diffusion temperature after driving in to oxidize and remove the HF resistant BRL. After diffusion, samples are dipped in $10 \%$ HF solution for more than 3 min to check if the surface remained hydrophilic, which indicates the presence of a BRL. High resistivity diffusion dummies were included in the diffusion to allow for measurement of the sheet resistance using a four-point probe. Sheet resistance measurements on the dummy wafers show that both sides of the wafers are doped by similar amounts, therefore the boron and phosphorus diffusion gettering is considered to be from both front and rear surfaces. For aluminum gettering, 99.999\% pure Al metal was first thermally evaporated on both sides, followed by annealing in $\mathrm{N}_{2}$ gas.

The variations in the process conditions are detailed in Table I. In addition to constant temperature diffusions between 850 to $950{ }^{\circ} \mathrm{C}$ for $\mathrm{BBr}_{3}$ and between 780 to $850{ }^{\circ} \mathrm{C}$ for $\mathrm{POCl}_{3}$, the gettering effectiveness of extended low temperature annealing or extended gettering ${ }^{27-29}$ between 600 and $650^{\circ} \mathrm{C}$ was also tested by ramping down the furnace temperature at an average rate of $10^{\circ} \mathrm{C} / \mathrm{min}$ after emitter formation at high temperature. Other than the extended gettering samples, the rest of the samples were removed from the furnaces at the diffusion temperature and were air-cooled to room temperature. The temperature of the wafers dropped to below $300^{\circ} \mathrm{C}$ within $1 \mathrm{~min}$ after removal from the furnace; therefore significant precipitation or re-distribution of $\mathrm{Fe}$ is avoided. After processing, about $10 \mu \mathrm{m}$ was etched from

TABLE I. Process conditions used for boron diffusion gettering, phosphorus diffusion gettering and aluminum alloying gettering.

\begin{tabular}{|c|c|c|c|c|c|c|c|c|c|c|c|}
\hline \multicolumn{4}{|c|}{ Boron } & \multicolumn{4}{|c|}{ Phosphorus } & \multicolumn{4}{|c|}{ Aluminum } \\
\hline Label & $\begin{array}{l}\text { Time } \\
(\mathrm{min})\end{array}$ & $T\left({ }^{\circ} \mathrm{C}\right)$ & $\begin{array}{c}\text { Sheet } \\
\text { resistance } \\
(\Omega / \square)\end{array}$ & Label & $\begin{array}{l}\text { Time } \\
(\min )\end{array}$ & $T\left({ }^{\circ} \mathrm{C}\right)$ & $\begin{array}{c}\text { Sheet } \\
\text { resistance } \\
(\Omega / \square)\end{array}$ & Label & $\begin{array}{l}\text { Time } \\
(\mathrm{min})\end{array}$ & $T\left({ }^{\circ} \mathrm{C}\right)$ & $\begin{array}{c}\mathrm{Al} \\
\text { thickness } \\
(\mu \mathrm{m})\end{array}$ \\
\hline B1-950C & 60 & 950 & 54 & P850C & 55 & 850 & 38 & $\mathrm{~A} 1850 \mathrm{C}$ & 55 & 850 & 0.64 \\
\hline B1-900C & 60 & 900 & 97 & P800C & 55 & 800 & 102 & Al850C-thin & 55 & 850 & 0.07 \\
\hline B1-850C & 60 & 850 & 141 & P780C & 72 & 780 & 145 & $\mathrm{~A} 1750 \mathrm{C}$ & 55 & 750 & 0.63 \\
\hline B1-950C +ext650C & $60+60$ & 650 & 50 & $\mathrm{P} 850 \mathrm{C}+\mathrm{ext} 650 \mathrm{C}$ & $55+60$ & 650 & 51 & Al750C-RTA & 15 s peak & 750 & 0.63 \\
\hline B1-850C +ext600C & $60+60$ & 600 & 140 & $\mathrm{P} 780 \mathrm{C}+\mathrm{ext} 650 \mathrm{C}$ & $72+60$ & 650 & 200 & & & & \\
\hline B2-950C + post-ox & 60 & 950 & 45 & & & & & & & & \\
\hline B2-950C + no post-ox & 60 & 950 & 43 & & & & & & & & \\
\hline
\end{tabular}

The time shown does not include the ramp up from $700{ }^{\circ} \mathrm{C}$. "ext" refers to the extended low temperature gettering, and the experiment conditions with the extended low temperature annealing started with the same diffusion as the first part of the label, followed by ramp down to the lower temperature in the furnace for extended annealing in $\mathrm{N}_{2}$ ambient for the time listed. For example, "P780+ext650C" had the same phosphorus diffusion as P780C for 72 min and then annealing at $650^{\circ} \mathrm{C}$ for an additional $60 \mathrm{~min}$. The boron diffusion sets $\mathrm{B} 2$ have double the $\mathrm{BBr}_{3}$ vapour concentration during the deposition process compared to $\mathrm{B} 1$, but the other process parameters such as main $\mathrm{N}_{2}$ flow and the $\mathrm{O}_{2}$ concentration are kept unchanged. For "BRL950C + no post-ox." the post oxidation step at the end is replaced with a $\mathrm{N}_{2}$ anneal. 
both sides for all samples, followed by surface passivation with SiN using PECVD at $450{ }^{\circ} \mathrm{C}$. Some high dose samples were also annealed in $\mathrm{N}_{2}$ at temperatures of 550, 650, 750, 800 , and $850^{\circ} \mathrm{C}$ for $1 \mathrm{~h}$ to check for precipitation of Fe. To check for possible precipitation during the $\mathrm{SiN}$ deposition process itself, the SiN layers were removed from some of the gettered samples and deposited again using the same settings for additional $\left[\mathrm{Fe}_{\mathrm{i}}\right]$ measurements.

The uncertainty of the measured $\left[\mathrm{Fe}_{\mathrm{i}}\right]$ was estimated by taking three repeated measurements, each time allowing for Fe-B re-pairing in the dark and calculating the upper and lower limit of $\left[\mathrm{Fe}_{\mathrm{i}}\right]$ based on an estimated uncertainty of $5 \%$ in the lifetime measurements. The largest lower and upper limits were then taken as the minimum lower limit and maximum upper limit of the three measurements, respectively.

\section{RESULTS AND DISCUSSION}

\section{A. Controls and precipitation}

First, to establish the baseline $\left[\mathrm{Fe}_{\mathrm{i}}\right]$ in the experiments to follow, Fig. 1 shows that the initial $\left[\mathrm{Fe}_{\mathrm{i}}\right]$ in the "as cut" control wafers, which did not undergo implantation or annealing in the furnace, is insignificant compared to the implanted doses. Second, the measured concentration for the annealed nonimplanted samples shows that the furnace contamination was around $1 \times 10^{11} \mathrm{~cm}^{-3}$. This level of furnace contamination is significant but is at least one order of magnitude lower than the lowest implanted dose, and therefore it does not affect the total $\left[\mathrm{Fe}_{\mathrm{i}}\right]$ dose significantly. Third, the samples used as precipitation controls show that there is no significant precipitation of $\mathrm{Fe}$ for annealing at temperatures higher than $650{ }^{\circ} \mathrm{C}$ for $1 \mathrm{~h}$. Figure 1 also indicates that $\left[\mathrm{Fe}_{\mathrm{i}}\right]$

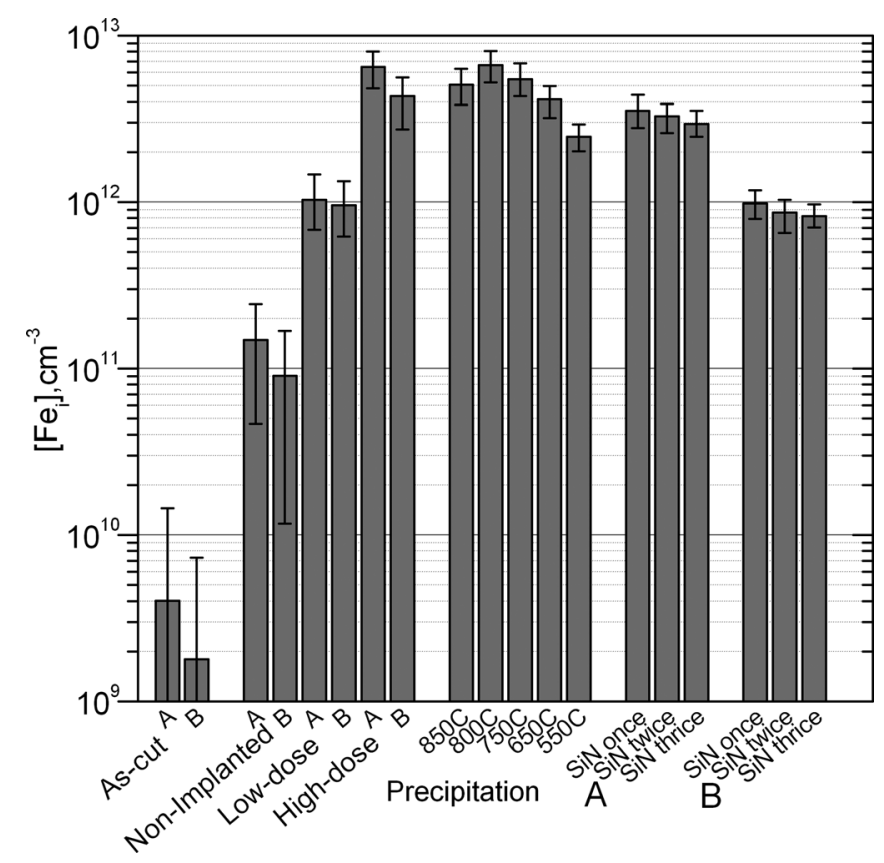

FIG. 1. Measured $\left[\mathrm{Fe}_{\mathrm{i}}\right]$ for different implant doses and the precipitation control samples. A and B are repetition of the same experiment with different wafers to check the consistency of the implanted dose. Note that the samples used for the $\mathrm{SiN}$ precipitation controls are different from the samples for the implant controls. decreases slightly after subsequent PECVD SiN depositions. However, the amount precipitated is minimal compared to the $\left[\mathrm{Fe}_{\mathrm{i}}\right]$ gettered during phosphorus diffusion, aluminum alloying, and some of the boron diffusion conditions. In any case, the same SiN deposition is applied for all measurements, so the small amount of Fe precipitation during surface passivation affects all measurements equally and cancels out when determining the gettering effectiveness. Therefore, the measured gettering efficiencies are considered to be unaffected by relaxation or precipitation gettering within the wafer bulk during annealing or SiN deposition.

Furthermore, most of the gettering conditions were for durations of at least $55 \mathrm{~min}$ as listed in Table I. At the lowest gettering temperature used of $600{ }^{\circ} \mathrm{C}$, the diffusion length of Fe in $55 \mathrm{~min}$ is estimated to be $220 \mu \mathrm{m}$ (Ref. 21) compared to the distance from the center of the wafer volume to the gettering region of $115 \mu \mathrm{m}$. Therefore the results will not be diffusion limited [with the exception of the rapid thermal annealed (RTA) Al sample, gettered for $15 \mathrm{~s}$, discussed separately in the following text]. If gettering is considered as a three step process of release, transport, and capture, ${ }^{30}$ the results from the experiments will therefore be mainly capture limited. As such, the results presented here, in single-crystal silicon with a fully dissolved concentration of interstitial iron, may not directly correlate with improvements in recombination lifetimes in multicrystalline silicon that may be release limited as well due to the dissolution of precipitated $\mathrm{Fe}$, other metal impurities which are less easily gettered, and dislocations and other defects that may act as competing gettering sites. Although the measured dose is more than a factor of 2 less than the target implant dose, the measured dose is consistent between repeat samples, and around $5.4 \times 10^{12}$ $\mathrm{cm}^{-3}$ for the high dose and $1 \times 10^{12} \mathrm{~cm}^{-3}$ for the low dose. For most of the gettering conditions considered, there is no significant dose dependence for the results with the exception of the "B1" recipes with extended gettering (discussed in the following text).

\section{B. Phosphorus diffusion gettering}

Consider first the standard phosphorus diffusion gettering (PDG) without extended low temperature annealing; Fig. 2 shows that it is effective in removing more than $90 \%$ of the interstitial $\mathrm{Fe}$ for the range of temperatures considered. Comparing the standard PDG at different temperature, it should be noted that a high sheet resistance PDG $(145 \Omega / \square)$ at a lower diffusion temperature of $780^{\circ} \mathrm{C}$ is more effective than a PDG at $850^{\circ} \mathrm{C}(38 \Omega / \square)$, despite the lower phosphorus concentration. This is in agreement with the results of Shabani et al. ${ }^{11}$ and indicates that the expected improvement in segregation coefficient due to lower temperature is sufficiently large to offset the effect of lower phosphorus doping especially when the diffusion time is long enough to allow for diffusion of Fe from the bulk to the gettering layers in both cases. Despite of this, the result for PDG with extended low temperature annealing clarifies the effect of heavier doping at the same gettering temperature of $650{ }^{\circ} \mathrm{C}$ and shows that PDG is more effective for higher phosphorus doping levels. 


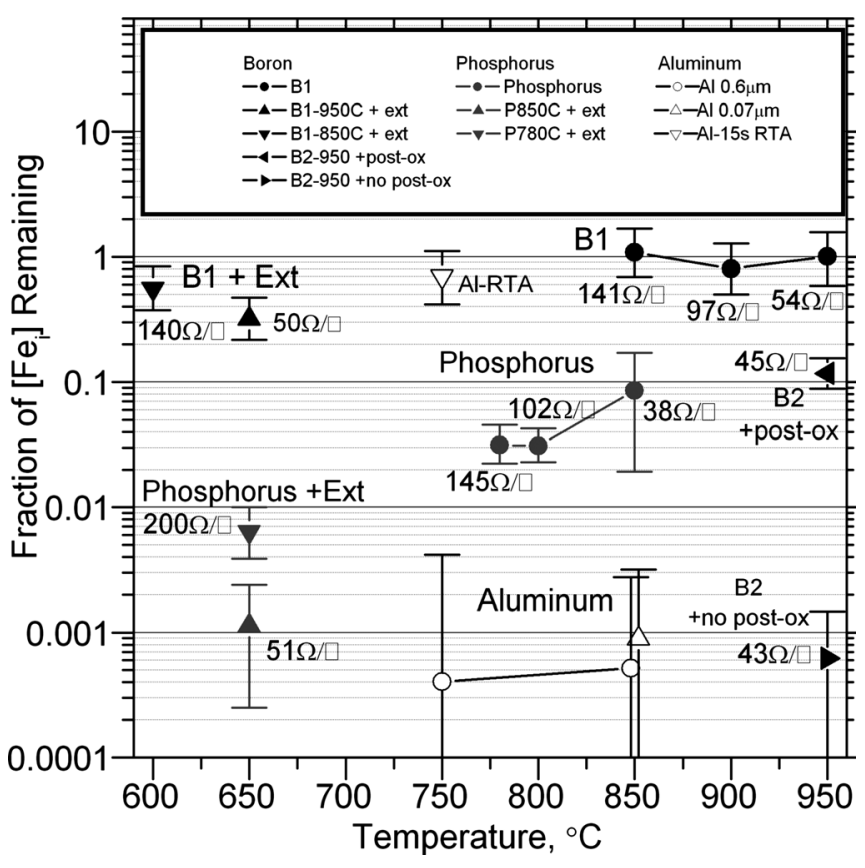

FIG. 2. Fraction of $\left[\mathrm{Fe}_{\mathrm{i}}\right]$ remaining after gettering relative to $\left[\mathrm{Fe}_{\mathrm{i}}\right]$ before gettering, as a function of the final annealing temperature, for high dose samples. Lower fraction represents more $\left[\mathrm{Fe}_{\mathrm{i}}\right]$ removed and better gettering effectiveness. Black filled symbols, gray filled symbols, and nonfilled symbols are for boron diffusion, phosphorus diffusion, and aluminum alloying, respectively. Sheet resistances for boron and phosphorus diffusion are shown for ease of reference. Results for aluminum alloying at $850^{\circ} \mathrm{C}$ are slightly displaced from the actual temperature to avoid overlapping of the error bars. Note that Al-15s RTA has a significantly shorter annealing time and is severely diffusion limited.

The results in Fig. 2 indicate that adding a low temperature annealing at $650{ }^{\circ} \mathrm{C}$ improves the gettering effectiveness by about a factor of 26 compared to the standard PDG at $850{ }^{\circ} \mathrm{C}$, which results in about $99.9 \%\left[\mathrm{Fe}_{\mathrm{i}}\right]$ removed. The $\mathrm{n}+$ doping is not expected to increase much during the low temperature annealing because of the limited diffusivity of phosphorus at $650{ }^{\circ} \mathrm{C}$, so the increase in gettering effectiveness is mainly due to the higher segregation coefficient at lower temperature. ${ }^{27,28,31}$ On the contrary, some of the phosphorus dopants may be electrically deactivated during the extended gettering. ${ }^{32}$ Separate measurements on phosphorus diffused wafers showed an increase in average sheet resistance from $49 \pm 1$ to $53 \pm 1 \Omega / \square$ after annealing at $650^{\circ} \mathrm{C}$ for $1 \mathrm{~h}$. Such an increase is also seen in Table I, where the sheet resistance increased for phosphorus diffused samples that were subjected to an additional low temperature anneal. Nevertheless, some of the increase in sheet resistance may also be attributed to process variations from batch to batch.

\section{Aluminum gettering}

Aluminum alloying gettering is found to be extremely effective $(>99.9 \%)$ at both 750 and $850{ }^{\circ} \mathrm{C}$, and the $\left[\mathrm{Fe}_{\mathrm{i}}\right]$ measurement results have reached the detection limit of the method as indicated by the lower error bars reaching the bottom of the graph in Fig. 2. Even when we attempted to decrease the gettering effectiveness by using a thinner aluminum layer of only $70 \mathrm{~nm}$, the gettering effectiveness only decreased slightly and remained close to the detection limit, showing that even very thin Al layers give excellent gettering.
When the anneal time was reduced to only $15 \mathrm{~s}$, as for the Al750C-RTA sample, the gettering effectiveness dropped to just $36 \%$. This annealing condition is similar to the Al back-surface field (BSF) firing step used in the fabrication of industrial silicon solar cells. Using a simplified model of $\mathrm{Fe}_{\mathrm{i}}$ diffusion based on Fick's second law of diffusion and assuming that the Al layer acts as an infinite sink, it is possible to predict that $37 \%$ of the Fe will be removed from the bulk for the thermal profile used in the experiment. The close agreement with our measured result shows that the gettering is diffusion limited in this case. The estimated diffusion length of $\mathrm{Fe}$ during the entire anneal step from standby to ramp down is only $33.5 \mu \mathrm{m} .^{21}$ This demonstrates that the standard industrial BSF formation on p-type solar cells would not be effective for gettering of $\mathrm{Fe}$, and any $\mathrm{Fe}$ that is removed will only come from the rear part of the device and not near the front junction, where gettering is most crucial.

\section{Boron diffusion gettering}

After HF dipping, only the "B2+ no post-ox" set had $100 \%$ BRL coverage on both sides, while the other samples all pulled dry completely in HF, indicating that no BRL was present. Figure 2 shows that boron diffusion gettering is completely ineffective for temperatures above $850{ }^{\circ} \mathrm{C}$ for the "B1" recipe used in this study. The poor gettering effectiveness can be explained by considering that the gettering is purely due to the enhanced solubility of Fe in the heavily boron-doped emitter as modeled by McHugo et al. ${ }^{17}$ The segregation coefficient for iron in the borondoped region, which is estimated to be 0.1 at $850{ }^{\circ} \mathrm{C}$ for $N_{\mathrm{B}}=1 \times 10^{20} \mathrm{~cm}^{-3},{ }^{17}$ coupled with the low thickness of the boron emitter layer that is estimated to be less than 0.5 $\mu \mathrm{m}$, means that the $\left[\mathrm{Fe}_{\mathrm{i}}\right]$ gettered would be less than $4 \%$. The nonimplanted samples indicate that the boron diffusions were in fact contaminating the wafers with $\mathrm{Fe}$, increasing $\left[\mathrm{Fe}_{\mathrm{i}}\right]$ after boron diffusion by about $6 \times 10^{11}$ $\mathrm{cm}^{-3}$, presumably coming from the furnace tube. Nevertheless this contamination level is insignificant compared to the high dose samples and does not affect the conclusion that boron diffusion gettering is ineffective above $850^{\circ} \mathrm{C}$ when using our standard "B1" recipe.

Adding a low temperature anneal was effective in increasing the segregation coefficient and was able to getter about $70 \%$ of the interstitial Fe for the high dose samples but was ineffective for the low dose samples with less than $4 \%\left[\mathrm{Fe}_{\mathrm{i}}\right]$ gettered. The furnace contamination as measured on the nonimplanted control samples was less than half of the $\left[\mathrm{Fe}_{\mathrm{i}}\right]$ of the low dose samples and thus cannot fully explain the poor gettering effectiveness for low dose samples. The dose dependence of the extended gettering suggests that the effect of the low temperature annealing is partly due to precipitation in the boron emitter region. It should be pointed out that Terakawa et al. reported a higher gettering effectiveness of up to $99 \% \mathrm{Fe}$ removed using $\mathrm{CZ}$ silicon wafers with annealing at $600{ }^{\circ} \mathrm{C}^{29}$ It is clear that the surface precipitation mechanism that they proposed was not effective in our 
experiment because more than half of the $\left[\mathrm{Fe}_{\mathrm{i}}\right]$ remained after gettering. This may be due to the differences in surface and boron diffusion conditions or because surface precipitation is slower in FZ wafers.

In the case of the " $\mathrm{B} 2$ " recipes with higher $\mathrm{BBr}_{3}$ concentration during deposition, the gettering effectiveness of the boron diffusion is greatly improved with close to $90 \%$ of the $\left[\mathrm{Fe}_{\mathrm{i}}\right]$ removed with the same postoxidation step as the "B1" recipes. As demonstrated by the results of the set "B2+ no post-ox," replacing the postoxidation with a $\mathrm{N}_{2}$ anneal and keeping the BRL improves the gettering effectiveness further, resulting in more than $99.9 \%$ of the $\left[\mathrm{Fe}_{\mathrm{i}}\right]$ removed, without an extended gettering step. The significant improvement in gettering effectiveness cannot be fully explained by the increased solubility in the slightly more heavily doped emitter in the "B2" recipe because the segregation coefficient is still only about 0.05 even if $N_{\mathrm{B}}$ is increased to $1 \times 10^{21}$ $\mathrm{cm}^{-3}$ at $950{ }^{\circ} \mathrm{C}^{17}$ Surface precipitation ${ }^{29}$ and formation of Si-B precipitates ${ }^{19}$ within the emitter region are insignificant as well because the"B2" diffusions were removed at temperature. Therefore we consider the segregation of Fe impurities into the $\mathrm{BRL}^{7}$ on the surface of the silicon wafer as the most likely explanation of the improved gettering effect. The dependence on the postoxidation step can be explained if the Fe segregated into the BRL is released back into the Si when the BRL is oxidized, noting that the diffusion length of $\mathrm{Fe}$ at $950^{\circ} \mathrm{C}$ for $6 \mathrm{~min}$ is about $250 \mu \mathrm{m}$.

The results show that with suitable conditions, boron diffusions can act as excellent gettering layers without the requirement for an additional low temperature anneal. This is contrary to expectations based solely on considering equilibrium segregation to the boron diffused layer and reflects the important role that the BRL can play.

\section{CONCLUSIONS}

The results indicate that boron diffusion, phosphorus diffusion, and aluminum alloying can all getter more than $99 \%$ of the dissolved $\mathrm{Fe}_{\mathrm{i}}$ in monocrystalline float zone silicon wafers with suitable adjustments and can also be potentially applied to improve the lifetime of multicrystalline silicon wafers. Phosphorus diffusion gettering is quite effective (90-95\%) for a range of temperatures and sheet resistances and can be improved further $(>99 \%)$ by means of an extended low temperature anneal. Aluminum alloying can be very effective as well but is likely diffusion limited, hence ineffective, due to the low thermal budget typically used in solar cell fabrication. Compared to phosphorus and aluminum gettering, boron diffusion gettering is very sensitive to the process parameters, likely requiring supersaturation of boron dopants. Doubling the vapor concentration of the boron source during deposition and changing the postoxidation step was found to increase the gettering effectiveness dramatically from less than $5 \%\left[\mathrm{Fe}_{\mathrm{i}}\right]$ removed to more than $99.9 \%$ removed. Such effectiveness of the boron diffusion gettering, without an additional low temperature anneal, cannot be explained by the model of impurity segregation to the boron-doped emitter, which suggests that the boron rich layer or $\mathrm{Si}-\mathrm{B}$ precipitates within the $\mathrm{p}+$ layer are effective traps for Fe and likely other harmful metal impurities. ${ }^{18}$ The impressive gettering effectiveness at high temperature, coupled with the high thermal budget required for boron diffusion, which can promote the release of impurities, suggest that a properly optimized boron diffusion step may have the potential to become an effective method for improving the carrier lifetime and conversion efficiency of n-type multicrystaline silicon solar cells.

\section{ACKNOWLEDGMENTS}

The authors would like to thank Chris Samundsett and Dr Jason Tan for assistance and guidance on processing, and Professor Rob Elliman and Dr Kidane Belay for assistance with ion implantation. Insightful discussions with Professor Andres Cuevas, Dr. Radovan Kopecek, and Dr. Joris Libal are much appreciated. This work has been supported by the Australian Research Council.

${ }^{1}$ A. Cuevas, M. J. Kerr, C. Samundsett, F. Ferrazza, and G. Coletti, Appl. Phys. Lett. 81, 4952 (2002).

${ }^{2}$ L. J. Geerligs, Y. Komatsu, I. Rover, K. Wambach, I. Yamaga, and T. Saitoh, J. Appl. Phys. 102, 9 (2007).

${ }^{3}$ V. D. Mihailetchi, L. J. Geerligs, Y. Komatsu, T. Buck, I. Röver, K. Wambach, C. Knopf, and R. Kopecek, 22nd European Photovoltaic Solar Energy Conference, Milan, Italy (WIP-Renewable Energies, Munich, Germany, 2008).

${ }^{4}$ D. Macdonald and L. J. Geerligs, Appl. Phys. Lett. 85, 4061 (2004).

${ }^{5}$ J. E. Cotter, J. H. Guo, P. J. Cousins, M. D. Abbott, F. W. Chen, and K. C. Fisher, IEEE Trans. Electron Devices 53, 1893 (2006).

${ }^{6}$ G. Coletti, R. Kvande, V. D. Mihailetchi, L. J. Geerligs, L. Arnberg, and E. J. Ovrelid, J. Appl. Phys. 104, 104913 (2008).

${ }^{7}$ J. Libal, R. Petres, T. Buck, R. Kopecek, G. Hahn, R. Ferre, M. Vetter, I. Martín, K. Wambach, I. Roever, and P. Fath, 20th European Photovoltaic Solar Energy Conference, Barcelona, Spain (WIP-Renewable Energies, Munich, Germany, 2005).

${ }^{8}$ A. A. Istratov, H. Hieslmair and E. R. Weber, Appl. Phys. A: Mater. Sci. Process. 70, 489 (2000).

${ }^{9}$ S. M. Myers, M. Seibt, and W. Schroter, J. Appl. Phys. 88, 3795 (2000).

${ }^{10}$ D. Macdonald, H. Mackel, and A. Cuevas, Appl. Phys. Lett. 88, 092105 (2006).

${ }^{11}$ M. B. Shabani, T. Yamashita, and E. Morita, Solid State Phenom. 131133, 399 (2008).

${ }^{12}$ R. Kopecek, T. Buck, J. Libal, I. Rover, K. Wambach, L. J. Geedligs, P. Sanchez-Friera, J. Alonso, E. Wefringhaus, and P. Fath, 4th World Conference on Photovoltaic Energy Conversion, Waikoloa, Hawaii (IEEE, New York, 2006)

${ }^{13}$ F. Dross, R. H. Franken, S. Singh, E. van Kerschaver, G. Beaucame, and R. Mertens, 33rd IEEE Photovoltaic Specialists Conference, New York (IEEE, New York, 2008).

${ }^{14}$ H. Hieslmair, S. McHugo, and E. R. Weber, 25th IEEE Photovoltaic Specialists Conference, Washington, D.C. (IEEE, New York, 1996).

${ }^{15}$ D. Abdelbarey, V. Kveder, W. Schroter, and M. Seibt, Appl. Phys. Lett. 94, 061912 (2009).

${ }^{16}$ M. Aoki, T. Itakura, and N. Sasaki, Appl. Phys. Lett. 66, 2709 (1995).

${ }^{17}$ S. A. McHugo, R. J. McDonald, A. R. Smith, D. L. Hurley, and E. R. Weber, Appl. Phys. Lett. 73, 1424 (1998).

${ }^{18}$ S. M. Myers, G. A. Petersen, T. J. Headley, J. R. Michael, T. L. Aselage, and C. H. Seager, Nucl. Instrum. Methods Phys. Res. B 127, 291 (1997).

${ }^{19}$ V. Vähänissi, A. Haarahiltunen, H. Talvitie, M. Yli-Koski, J. Lindroos, and H. Savin, Phys. Status Solidi (RRL) 4, 136 (2010).

${ }^{20}$ M. A. Kessler, T. Ohrdes, B. Wolpensinger, and N. P. Harder, Semicond. Sci. Technol. 25, 055001 (2010).

${ }^{21}$ A. A. Istratov, H. Hieslmair, and E. R. Weber, Appl. Phys. A: Mater. Sci. Process. 69, 13 (1999).

${ }^{22}$ D. Macdonald, P. N. K. Deenapanray, and S. Diez, J. Appl. Phys. 96, 3687 (2004). 
${ }^{23}$ R. A. Sinton and A. Cuevas, Appl. Phys. Lett. 69, 2510 (1996).

${ }^{24}$ G. Zoth and W. Bergholz, J. Appl. Phys. 67, 6764 (1990).

${ }^{25}$ D. Macdonald, L. J. Geerligs, and A. Azzizi, J. Appl. Phys. 95, 1021 (2004).

${ }^{26}$ D. Macdonald, T. Roth, P. N. K. Deenapanray, T. Trupke, and R. A. Bardos, Appl. Phys. Lett. 89, 142107 (2006).

${ }^{27}$ J. Harkonen, V. P. Lempinen, T. Juvonen, and J. Kylmaluoma, Sol. Energy Mater. Sol. Cells 73, 125 (2002).
${ }^{28}$ P. Manshanden and L. J. Geerligs, Sol. Energy Mater. Sol. Cells 90, 998 (2006).

${ }^{29}$ T. Terakawa, D. Wang, and H. Nakashima, Jpn. J. Appl. Phys. Part 145 , 2643 (2006).

${ }^{30}$ J. S. Kang and D. K. Schroder, J. Appl. Phys. 65, 2974 (1989).

${ }^{31}$ A. Haarahiltunen, H. Savin, M. Yli-Koski, H. Talvitie, and J. Sinkkonen, J. Appl. Phys. 105, 023510 (2009).

${ }^{32}$ L. Morettini and D. Nobili, Mater. Chem. Phys. 10, 21 (1984). 